\author{
B.K. Zhumashev ${ }^{1}$, R.R. Beisenova ${ }^{1}$, M.R. Khanturin ${ }^{1}$, K.A. Zhumasheva ${ }^{2}$ \\ ${ }^{I}$ L.N. Gumilyov Eurasian National University, Nur-Sultan, Kazkhstan; \\ ${ }^{2}$ Ye.A. Buketov Karaganda State University, Kazakhstan; \\ (E-mail: nubtuber.13@gmail.com)
}

\title{
Observing of air quality in cities of Central Kazakhstan
}

\begin{abstract}
The problem of air quality occupies a special place among the problems of environmental protection. This is due primarily to the vital need for atmospheric air for all life on Earth, and the influence of the state of the atmosphere on global climatic processes and the biosphere as a whole due to the enormous mobility of air masses with which harmful impurities can be transported. These issues are especially relevant for the old industrial regions, where the level of anthropogenic impact has reached a critical value, one of these regions is central Kazakhstan. This article has collected data for the last 3.5 years, particalary the quantitative content of the main pollutants, from suspended particles (PM-10 and smaller) to various chemical compounds such as carbon dioxide or nitric oxide. Observation of atmospheric air by government is an integral part of the Unified State System for Monitoring the Environment and Natural Resources and is carried out in accordance with the legislation of the Republic of Kazakhstan in the field of environmental protection.
\end{abstract}

Keywords: ultrafine particles matters, maximum permissible concentration, atmospheric pollution index, standard index, highest repeatability, high pollution, extremely high pollution, solid particles, World Health Organization.

\section{Introduction}

According to the law of the Republic of Kazakhstan «On the protection of the health of the people in the Republic of Kazakhstan» in the definition of «environment» atmospheric air, drinking water and soil are noted as environmental elements that have or, under certain conditions, can have an effect (positive or negative) on the health of the population [1].

In recent decades, significant progress has been made in medical science in studying the biological role of the chemical composition of air and its possible impact on the body and public health. However, the data is often controversial. Thus, studies of air pollution on the development of various pathologies gave conflicting results [2].

The effect of polluted air on human health has long been beyond doubt [2]. But the pollution entering the atmosphere certainly gets into the water, soil, plants, meat of domestic animals. As a result, a person suffers, because along these biological chains the chemical elements of all media will still affect his health [3].

According to estimates of the World Health Organization in 2014, air pollution every year leads to premature death of about 7 million people worldwide [4]. Studies published in March 2019 showed that their number could be about 8.8 million [5].

The degree of air pollution by an impurity is estimated by comparing the concentration of impurities with MPC (in $\mathrm{mg} / \mathrm{m}^{3}, \mu \mathrm{g} / \mathrm{m}^{3}$ ). MPC — maximum permissible impurity concentration. To assess the level of air pollution per month, two indicators of air quality are used [6]:

- Standard Index (SI) - the largest measured in the city maximum single concentration of any pollutant, divided by MPC.

- The greatest repeatability; (NP),\%, MPC excess - the highest repeatability of MPC excess by any pollutant in the air of the city.

- Atmospheric Pollution Index (IZA) is an indicator of air pollution. For its calculation, the average concentrations of various pollutants are used, divided by MPC and reduced to the harmfulness of sulfur dioxide. The degree of air pollution is characterized by four standard gradations of indicators SI, NP and IZA. If IZA, SI and NP fall into different gradations, then the degree of air pollution is estimated by IZA [7].

The aim of our study was to study the dynamics of atmospheric air pollution in industrial cities of Central Kazakhstan. We have analyzed the data for the last 3.5 years collected [8-15] at stationary posts by specialized units of the RSE «Kazhydromet».As a result of this period of time, 7004 cases of airborne diseases and 906 cases of EHP were recorded throughout Kazakhstan, of which 340 cases of airborne diseases 
and 7 EHP's were registered in the cities of the Karaganda region mainly: Balkhash, Temirtau, Karaganda, however, these isolated cases cannot provide full pictures, therefore, for its compilation, data were used on the excess of MCP for specific pollutants, and standard indicators of air quality [6].

After monitoring atmospheric pollution in the city of Nur-Sultan, [8-11] collected at stationary posts by specialized units of the RSE «Kazhydromet» for 2016-2019, the data are shown in Table 1.

T a b l e 1

Indices of atmospheric air of the city of Nur-Sultan

\begin{tabular}{|c|c|c|c|c|c|c|c|c|c|c|c|c|}
\hline & & & & Main & \multicolumn{8}{|c|}{ Number of cases of exceeding the MPC $>1$} \\
\hline & IZA & SI & HR & pollution & $\mathrm{PM}<2.5$ & PM-2.5 & PM-10 & $\mathrm{SO}_{2}$ & $\mathrm{NO}_{2}$ & $\mathrm{NO}$ & $\mathrm{HF}$ & $\mathrm{CO}$ \\
\hline 2016 & 7 & 8 & $52 \%$ & $\mathrm{NO}_{2}$ & 997 & 35 & 1048 & 1323 & 626 & 3 & 78 & 48 \\
\hline 2017 & 6 & 9 & $27 \%$ & $\mathrm{NO}_{2}$ & 548 & 251 & 143 & 50 & 738 & & 54 & 102 \\
\hline 2018 & 7 & 17 & $0 \%$ & $\begin{array}{c}\mathrm{NO}_{2} \\
\mathrm{PM}<2.5 \\
\mathrm{PM}-2.5\end{array}$ & 1228 & 923 & 397 & 378 & 627 & 56 & 26 & 289 \\
\hline 2019 & 1 & 1 & $0 \%$ & $\mathrm{HF}$ & 350 & 2276 & 710 & & 291 & 302 & 70 & 277 \\
\hline
\end{tabular}

As can be seen from Table 1, the main sources of pollution of the city of Nur-Sultan are suspended UDM especially PM-2.5, as well as nitrogen dioxide. The main sources of anthropogenic formations of these contaminants are smoke and soot generated mainly during the combustion of solid and liquid hydrocarbons (For example: heating houses, generating electricity, working engines of cars, ships and aircraft). As you know, the $\mathrm{NO}_{2}$ air pollutant acts in several interconnected ways [7]:

- If the concentration level of $200 \mu \mathrm{g} / \mathrm{m}^{3}$ is briefly exceeded, 3 nitrogen dioxide is a toxic gas that causes severe airway inflammation [5].

$-\mathrm{NO}_{2}$ is the main source of nitrate aerosols that form one of the main fractions of PM2.5, and ozone in the presence of ultraviolet light.

Epidemiological studies have shown that symptoms of bronchitis in children with asthma are exacerbated by prolonged exposure to $\mathrm{NO}_{2}$ [3]. Decreased lung function is also associated with $\mathrm{NO}_{2}$ exposure at current levels recorded (or observed) in many cities.

In contrast to the capital, the cities of the Karaganda region are formed by large enterprises of heavy industry, for example, the Balkhash «Non-Ferrous Metals Processing Plant» or «Zhezkazgantsvetmet», and given the growing amount of motor transport combined with the continued use of thermal power plants, the anthropogenic impact in this region is much more pronounced, this is reflected in the annual report since in the cities of this region a greater number of pollutants (phenol, ammonia, hydrogen sulfide) are recorded, and the number of UDM is many times greater.

After monitoring the atmospheric air pollution in the city of Karaganda [12-15], collected at stationary posts by specialized units of the RSE «Kazhydromet» for 2016-2019, the data are shown in Table 2.

T a b l e 2

Indices of atmospheric air of the city of Karaganda

\begin{tabular}{|c|c|c|c|c|c|c|c|c|c|c|c|c|c|c|}
\hline & \multirow{2}{*}{ IZA } & \multirow{2}{*}{ SI } & \multirow{2}{*}{ HR } & \multirow{2}{*}{$\begin{array}{c}\text { Main } \\
\text { pollution }\end{array}$} & \multicolumn{10}{|c|}{ Number of cases of exceeding the MPC $>1$} \\
\hline & & & & & $\mathrm{PM}<2.5$ & PM-2.5 & PM-10 & $\mathrm{SO}_{2}$ & $\mathrm{CO}$ & $\mathrm{NO}_{2}$ & $\mathrm{O}_{3}$ & $\mathrm{H}_{2} \mathrm{~S}$ & Phenol & $\mathrm{NH}_{3}$ \\
\hline 2016 & 8 & 21 & $17 \%$ & PM-2.5 & 10 & 5313 & 2149 & & 1778 & 151 & 266 & 30 & 93 & 2 \\
\hline 2017 & 8 & 16 & & PM-2.5 & 16 & 7378 & 3105 & & 642 & 444 & 9 & 29 & 96 & \\
\hline 2018 & 10 & 21 & $31 \%$ & $\begin{array}{c}\text { PM-2.5 } \\
\text { Methane } \\
\text { CO }\end{array}$ & 90 & 9928 & 5333 & 7 & 4179 & 11 & & 316 & 61 & 3 \\
\hline 2019 & 9 & 20 & & PM-2.5 & 34 & 3697 & 1766 & & 186 & 12 & 969 & 99 & 1 & \\
\hline
\end{tabular}

As can be seen from the statistics presented in table 2, the main type of pollutant is UDM, in particular RM-2.5, and carbon monoxide. PM concentration is a frequently used indirect indicator of air pollution. They have a negative effect on more people [4] than any other air pollutant. The main components of PM are sulfates, nitrates, ammonia, sodium chloride, soot, mineral dust and water. They consist of a complex mixture of solid and liquid organic and inorganic substances present in suspension in the air. Particles with a diameter of less than 10 microns $(\leq$ PM10) are able to penetrate deep into the lungs and precipitate in them. 
Particles with a diameter of less than 2.5 microns ( $\leq$ PM2.5) have even more devastating health effects. They can cross the airborne barrier and enter the circulatory system. Chronic exposure to particulate matter aggravates the risk of developing cardiovascular, respiratory, and oncological diseases.

After monitoring the air pollution in the city of Balkhash [16-19], collected at stationary posts by specialized units of the RSE «Kazhydromet» for 2016-2019, the data are shown in Table 3.

$\mathrm{Tab} l \mathrm{e} 3$

\section{Indices of atmospheric air of the city of Balkhash}

\begin{tabular}{|c|c|c|c|c|c|c|c|c|c|c|c|c|}
\hline & \multirow{2}{*}{ IZA } & \multirow{2}{*}{$\mathrm{SI}$} & \multirow{2}{*}{$\mathrm{HR}$} & \multirow{2}{*}{$\begin{array}{c}\text { Main } \\
\text { pollutin }\end{array}$} & \multicolumn{8}{|c|}{ Number of cases of exceeding the MPC $>1$} \\
\cline { 6 - 14 } & & & & & $\mathrm{PM}<2.5$ & $\mathrm{PM}-2.5$ & $\mathrm{PM}-10$ & $\mathrm{SO}_{2}$ & $\mathrm{CO}$ & $\mathrm{NO}_{2}$ & $\mathrm{O}_{3}$ & $\mathrm{H}_{2} \mathrm{~S}$ \\
\hline 2016 & 7 & 24 & $3 \%$ & $\mathrm{SO}_{2}$ & 47 & 372 & 146 & 558 & 5 & 13 & 22 & 227 \\
\hline 2017 & 6 & 20 & & $\mathrm{SO}_{2}, \mathrm{H}_{2} \mathrm{~S}$ & 73 & & & 428 & 45 & 35 & & 554 \\
\hline 2018 & 7 & 23 & & $\mathrm{SO}_{2}, \mathrm{H}_{2} \mathrm{~S}$ & 69 & & & 480 & 89 & 3 & 1 & 564 \\
\hline 2019 & & 8 & $2 \%$ & $\mathrm{SO}_{2}$ & 8 & 40 & 10 & 120 & 2 & & 8 & 57 \\
\hline
\end{tabular}

Based on the data presented in Table 3, it is clearly seen that hydrogen sulfide and sulfur dioxide are the main pollutants in the city of Balkhash and the adjacent territories, the average annual concentration of these substances for 3.5 years was $\mathrm{SO}_{2}-30 \mu \mathrm{g} / \mathrm{m}^{3}$, and for $\mathrm{H}_{2} \mathrm{~S}-1 \mu \mathrm{g} / \mathrm{m}^{3}$. However, it is worth noting that the number of cases exceeding the maximum permissible concentrations of 5 and 10 times for the studied period of time was 115 times for $\mathrm{SO}_{2}(\mathrm{MCP}>5)$, and for $80 \mathrm{H}_{2} \mathrm{~S},(\mathrm{MCP}>5)-30$ cases, $(\mathrm{MCP}>10)-30$ cases [12-15]. The above values indicate that on the territory of the city of Balkhash there is a constant local source of emissions of pollutants, and quite strong.

The state of the environment in general, and the composition of air, water, and soil, in particular, are undoubtedly influenced by human activity, which often causes anthropogenic pollution. The activities of industrial complexes located in the territories of such cities as Karaganda, Balkhash, Zhezkazgan, Temirtau are a gross interference in the natural ecosystem, which leads to significant changes in environmental factors, and, therefore, affects the state of public health. Air intake directly into the human body is inevitable under all conditions. Therefore, the composition of atmospheric air, its purity, and the content of certain chemical elements in it are the main ones in assessing the environment.

Also, after monitoring atmospheric pollution in Zhezkazgan [20-23], collected at stationary posts by specialized units of the RSE «Kazhydromet» for 2016-2019, the data are shown in Table 4.

Ta a le 4

Indices of atmospheric air of the city of Zhezkazgan

\begin{tabular}{|c|c|c|c|c|c|c|c|c|c|c|c|c|c|c|}
\hline & \multirow{2}{*}{ IZA } & \multirow{2}{*}{ SI } & \multirow{2}{*}{ HR } & \multirow{2}{*}{$\begin{array}{c}\text { Main } \\
\text { pollution }\end{array}$} & \multicolumn{10}{|c|}{ Number of cases of exceeding the MPC $>1$} \\
\hline & & & & & $\mathrm{PM}<2.5$ & PM-2.5 & PM-10 & $\mathrm{SO}_{2}$ & $\mathrm{CO}$ & $\mathrm{NO}_{2}$ & $\mathrm{O}_{3}$ & $\mathrm{H}_{2} \mathrm{~S}$ & Phenol & $\mathrm{NH}_{3}$ \\
\hline 2016 & 7 & 10 & $17 \%$ & $\mathrm{H}_{2} \mathrm{~S}$ & 107 & 21 & 109 & 45 & 29 & 7 & 184 & 693 & 270 & \\
\hline 2017 & 8 & 9 & $31 \%$ & $\mathrm{H}_{2} \mathrm{~S}$ & 255 & 67 & 122 & 90 & 26 & 5 & & 2689 & 505 & 1 \\
\hline 2018 & 7 & 19,6 & & $\mathrm{H}_{2} \mathrm{~S}$ & 343 & & & 58 & 31 & 21 & & 8506 & 343 & \\
\hline 2019 & & 7,8 & $29 \%$ & $\mathrm{H}_{2} \mathrm{~S}$ & 230 & & & 2 & 6 & & & 481 & 167 & \\
\hline
\end{tabular}

As can be seen from the data presented in Table 4, it is noticeable that hydrogen sulfide is the main health hazard for residents of Zhezkazgan. The excess cases (MPC $>5$ ) amounted to 891 cases, and (MPC $>10)-15$ cases, the average annual concentration was $5.75 \mu \mathrm{g} / \mathrm{m}^{3}$, which is approximately 3.5 times less than the permissible norm [1], but do not forget that hydrogen sulfide very toxic: acute human poisoning occurs already at concentrations of $20-30 \mu \mathrm{g} / \mathrm{m}^{3}$, a concentration above $100 \mu \mathrm{g} / \mathrm{m}^{3}$ is fatal, with chronic intoxication a mutagenic and teratogenic effect is observed.

It is known that Temirtau [23-27] has perhaps one of the worst environmental conditions in our Republic, this is due primarily to the presence of large coke and chemical plants and ferrous metallurgy and steel smelting, as well as the presence of a number of coal mines.

After monitoring atmospheric pollution in Temirtau, collected at stationary posts by specialized units of the RSE «Kazhydromet» for 2016-2019, the data are shown in Table 5. 
Table 5

Indices of atmospheric air of the Temirtau city

\begin{tabular}{|c|c|c|c|c|c|c|c|c|c|c|c|c|}
\hline & \multirow{2}{*}{ IZA } & \multirow{2}{*}{$\mathrm{SI}$} & \multirow{2}{*}{$\mathrm{HR}$} & \multirow{2}{*}{$\begin{array}{c}\text { Main } \\
\text { pollution }\end{array}$} & \multicolumn{6}{|c|}{ Number of cases of exceeding the MPC $>1$} \\
\cline { 6 - 13 } & & & & & $\mathrm{PM}<2.5$ & $\mathrm{NO}$ & $\mathrm{SO}_{2}$ & $\mathrm{CO}$ & $\mathrm{NO}_{2}$ & $\mathrm{H}_{2} \mathrm{~S}$ & $\mathrm{Phenol}$ & $\mathrm{NH}_{3}$ \\
\hline 2016 & 8 & 11 & $27 \%$ & $\mathrm{SO}_{2}, \mathrm{NO}_{2}$ & 114 & 176 & 2060 & 106 & 2036 & 1557 & 593 & 26 \\
\hline 2017 & 8 & 12 & & $\mathrm{SO}_{2}, \mathrm{H}_{2} \mathrm{~S}$ & 296 & 3 & 1604 & 201 & 561 & 2444 & 451 & 47 \\
\hline 2018 & 8 & 13,5 & & $\mathrm{SO}_{2}, \mathrm{NO}_{2}$ & 169 & 92 & 1858 & 137 & 1693 & 1302 & 594 & 31 \\
\hline 2019 & & 12 & & $\mathrm{SO}_{2}, \mathrm{NO}_{2}$ & 450 & 67 & 1479 & 15 & 3749 & 1276 & 422 & 1 \\
\hline
\end{tabular}

As can be seen from Table 5 in Temirtau, in contrast to the above cities, there are more stable pollutants whose emissions exceed the PCD by 5 times: $\mathrm{SO}_{2}-175$ cases, $\mathrm{NO}_{2}-816$ cases, $\mathrm{H}_{2} \mathrm{~S}-180$ cases, it is also worth considering cases of exceeding the PCD by 10 times: $\mathrm{SO}_{2}-1$ case, $\mathrm{NO}_{2}-64 \mathrm{H}_{2} \mathrm{~S}-9$ cases. The average annual concentrations for 3.5 years according to these pollutants were: $\mathrm{SO}_{2}-54.25 \mu \mathrm{g} / \mathrm{m}^{3}$, $\mathrm{NO}_{2}-37.75 \mu \mathrm{g} / \mathrm{m}^{3}, \mathrm{H}_{2} \mathrm{~S}-22.5 \mu \mathrm{g} / \mathrm{m}^{3}$ [12-15].

According to the data published annually by the specialized units of the RSE «Kazhydromet» $[6,10]$ on environmental monitoring, all the cities studied in the period from 2016 to 2019 had a high level of pollution. Such a level of air pollution in settlements is caused by such pollutants as: nitrogen dioxide, carbon monoxide, sulfur dioxide, formaldehyde, hydrogen sulfide, suspended solids, phenol, ammonia is caused by:

- The load of roads by urban transport - the multicomponent exhaust emissions of gasoline and diesel fuel of vehicles is one of the main sources of air pollution of settlements with nitrogen dioxide, carbon monoxide, organic substances, etc., and high congestion of roads even in cities with good ventilation leads to accumulation harmful impurities in the atmosphere.

- The dispersion of emissions from industrial enterprises - the result of production processes during the combustion of industrial products is the entire list of harmful substances that cause high levels of air pollution. Their dispersal in the air basin over the territory of settlements significantly affects the air quality of cities, suburbs and villages.

- Low ventilation of the atmospheric space of settlements - airborne pollutants accumulate in the surface layer of the atmosphere, and their concentration remains at a very high level.

In this article, we would like to emphasize that the untimely transition of energy and heavy industry enterprises to more environmentally friendly raw materials and methods of processing them, as well as the technological backwardness of the Kazakhstan car fleet and the low level of «awareness» by the population of their own impact on the environment, can comprehensively irreparably worsen the ecological situation in our country and neighboring regions.

\section{References}

1 Закон Республики Казахстан «Об охране здоровья народа в Республике Казахстан». - Алма-Ата, 1992. — С. 3. Режим доступа: https://online.zakon.kz/Document/? doc_id=1000904.html.

2 Большакова А.М. Оценка риска влияния загрязнения атмосферного воздуха бензолом на здоровье населения / А.М. Большакова, В.Н. Осипова, Е.Ю. Романовская, Л.А. Ярославская // Гигиена и санитария. — 2000. — № 6. — С. 24-28.

3 Агаев Ф.Б. Некоторые методические аспекты использования показателей заболеваемости и смертности населения при создании гигиенического мониторинга / Ф.Б. Агаев, А.С. Кулиев, А.Г. Акбаров, М.Ш. Гасанов // Гигиена и санитария. - 1992. — № 11, 12. - С. 70-72.

4 Выпуск новостей 25 марта 2014 «7 миллионов смертей ежегодно связаны с загрязнением воздуха» // Сайт ВОЗ. [ЭР]. Режим доступа: https://www.who.int/ru/news-room/detail/25-03-2014-7-million-premature-deaths-annually-linked-to-airpollution.html.

5 Карингтон Д. Смертность от загрязнения воздуха превысила ожидаемые оценки в два раза / Д. Карингтон // TheGuardian. - [ЭР]. Режим доступа: https://www.theguardian.com/environment/2019/mar/12/air-pollution-deaths-are-doubleprevious-estimates-finds-research.html.

6 Gardiner H. Beijing's Air Would Be Called Good In Delhi / H. Gardiner // The New York Times International, Weekly (2 Feburary). - 2014. - P. 9-17.

7 Опаловский А.А. Планета Земля глазами химика / А.А. Опаловский. — М.: Наука, 1990. — 224 с.

8 РГП «Казгидромет». Состояние загрязнения атмосферного воздуха по городу Астане / РГП «Казгидромет» // Информационный бюллетень о состоянии окружающей среды. - 2016. - С. 212, 213.

9 РГП «Казгидромет». Состояние загрязнения атмосферного воздуха по городу Астане / РГП «Казгидромет» // Информационный бюллетень о состоянии окружающей среды. — 2017. - С. 138, 139. 
10 РГП «Казгидромет». Состояние загрязнения атмосферного воздуха по городу Астане / РГП «Казгидромет» // Информационный бюллетень о состоянии окружающей среды. - 2018. - С. 189, 190.

11 РГП «Казгидромет». Состояние загрязнения атмосферного воздуха по городу Нур-Султану / РГП «Казгидромет» // Информационный бюллетень о состоянии окружающей среды за 1 полугодие 2019 г. - 2019. - С. $95-97$.

12 РГП «Казгидромет». Состояние окружающей среды Карагандинской области (город Караганда) / РГП «Казгидромет» // Информационный бюллетень о состоянии окружающей среды. - 2016. - С. 310, 311.

13 РГП «Казгидромет». Состояние окружающей среды Карагандинской области (город Караганда) / РГП «Казгидромет» // Информационный бюллетень о состоянии окружающей среды. - 2017. - С. 239-241.

14 РГП «Казгидромет». Состояние окружающей среды Карагандинской области (город Караганда) / РГП «Казгидромет» // Информационный бюллетень о состоянии окружающей среды. — 2018. — С. 291-295.

15 РГП «Казгидромет». Состояние окружающей среды Карагандинской области (город Караганда) / РГП «Казгидромет» // Информационный бюллетень о состоянии окружающей среды за 1 полугодие 2019 г. — 2019. - С. 211-213.

16 РГП «Казгидромет». Состояние окружающей среды Карагандинской области (город Балхаш) / РГП «Казгидромет» // Информационный бюллетень о состоянии окружающей среды. - 2016. - С. 313.

17 РГП «Казгидромет». Состояние окружающей среды Карагандинской области (город Балхаш) / РГП «Казгидромет» // Информационный бюллетень о состоянии окружающей среды. - 2017. - С. 243.

18 РГП «Казгидромет». Состояние окружающей среды Карагандинской области (город Балхаш) / РГП «Казгидромет» // Информационный бюллетень о состоянии окружающей среды. — 2018. — С. 295.

19 РГП «Казгидромет». Состояние окружающей среды Карагандинской области (город Балхаш) / РГП «Казгидромет» // Информационный бюллетень о состоянии окружающей среды за 1 полугодие 2019 г. — 2019. - С. 215.

20 РГП «Казгидромет». Состояние окружающей среды Карагандинской области (город Жезказган) / РГП «Казгидромет» // Информационный бюллетень о состоянии окружающей среды. - 2016. - С. 314.

21 РГП «Казгидромет». Состояние окружающей среды Карагандинской области (город Жезказган) / РГП «Казгидромет» // Информационный бюллетень о состоянии окружающей среды. - 2017. - С. 245.

22 РГП «Казгидромет». Состояние окружающей среды Карагандинской области (город Жезказган) / РГП «Казгидромет» // Информационный бюллетень о состоянии окружающей среды. — 2018. — С. 297.

23 РГП «Казгидромет». Состояние окружающей среды Карагандинской области (город Жезказган) / РГП «Казгидромет» // Информационный бюллетень о состоянии окружающей среды за 1 полугодие 2019 г. — 2019. — С. 218.

24 РГП «Казгидромет». Состояние окружающей среды Карагандинской области (город Темиртау) / РГП «Казгидромет» // Информационный бюллетень о состоянии окружающей среды. - 2016. — С. 317.

25 РГП «Казгидромет». Состояние окружающей среды Карагандинской области (город Темиртау) / РГП «Казгидромет» // Информационный бюллетень о состоянии окружающей среды. - 2017. - С. 247.

26 РГП «Казгидромет». Состояние окружающей среды Карагандинской области (город Темиртау) / РГП «Казгидромет» // Информационный бюллетень о состоянии окружающей среды. - 2018. - С. 300.

27 РГП «Казгидромет». Состояние окружающей среды Карагандинской области (город Темиртау) / РГП «Казгидромет» // Информационный бюллетень о состоянии окружающей среды за 1 полугодие 2019 г. — 2019. — С. 220.

\section{Б.К. Жумашев, Р.Р. Бейсенова, М.Р. Хантурин, К.А. Жумашева Орталық Қазақстан қалаларындағы
атмосфералық ауа сапасының мониторингі}

Қоршаған ортаны қорғау мәселесі арасында ауа сапасының орыны ерекше. Бұл ең алдымен, жер бетіндегі барлық тіршілік иелері үшін атмосфералық ауаның өмірлік қажеттілігі және зиянды қоспалар тасымалдайтын ауа массаларының орасан қозғалғыштығына және ғаламдық климаттық процестердің ауаға ықпалы мен биосфераға байланысты. Бұл мәселелер антропогендік әсер ету деңгейі сыни дәрежеге жеткен ескі өнеркәсіптік өңірлер үшін ерекше өзекті болып саналады, осындай өңірлердің бірі Орталық Қазақстан болып табылады. Мақалада соңғы 3,5 жылдағы деректер, атап айтқанда, көмірқышқыл газы немесе азот оксиді сияқты өлшенген бөлшектерден (ТЧ-10 және одан да көп ұсақ) әртүрлі химиялық қосылыстарға дейінгі негізгі ластаушы заттардың сандық құрамы жинақталған. Атмосфералық ауаның жай-күйін бақылау мемлекеттік органдардың қоршаған орта мен табиғи ресурстар жай-күйі мониторингі бірыңғай мемлекеттік жүйенің ажырамас бөлігі болып табылады және Қазақстан Республикасының Қоршаған ортаны қорғау саласындағы заңнамасына сәйкес жүзеге асырылады.

Кілт сөздер: ультрадисперсты бөлшектер, поллютант, шекті рұқсат етілген концентрация, атмосфера ластануының индексі, стандартты индекс, жоғары қайталанушылық, жоғары ластану, экстремальды жоғары ластану, қатты бөлшектер, ДДСҰ. 


\title{
Б.К. Жумашев, Р.Р. Бейсенова, М.Р. Хантурин, К.А. Жумашева \\ Мониторинг качества атмосферного воздуха городов Центрального Казахстана
}

\begin{abstract}
Проблема качества атмосферного воздуха занимает особое место среди проблем охраны окружающей природной среды. Это обусловлено, прежде всего, жизненной необходимостью атмосферного воздуха для всего живого на Земле и влиянием состояния атмосферы на глобальные климатические процессы и биосферу в целом за счет огромной подвижности воздушных масс, с которыми могут переноситься вредные примеси. Особенно актуальны эти вопросы для старопромышленных регионов, где уровень антропогенного воздействия достиг критической величины, одним из таких регионов является Центральный Казахстан. В статье собраны данные за последние 4 года, а именно: количественное содержание основных загрязнителей (от взвешанных частиц [РМ-10 и более мелкие] до различных химических соединений, таких как диоксид углерода или оксид азота). Степень загрязнения атмосферного воздуха примесями оценивалась при сравнении концентрации примесей с ПДК (в мг $/ \mathrm{M}^{3}$, мкг $\left./ \mathrm{M}^{3}\right)$. Регион Центрального Казахстана был выбран не случайно, так как его каждый крупный город представлен одним или несколькими предприятиями тяжёлой промышленности.
\end{abstract}

Ключевые слова: ультрадисперсные частицы, поллютант, предельно допустимая концентрация, индекс загрязнения атмосферы, стандартный индекс, наибольшая повторяемость, высокое загрязнение, экстремально высокое загрязнение, твёрдые частицы, ВОЗ.

\section{References}

1 Zakon Respubliki Kazakhstan «Ob okhrane zdorovia naroda v Respublike Kazakhstan» [The Law of the Republic of Kazakhstan «On the Protection of the Health of the People in the Republic of Kazakhstan»]. (1992). Alma-Ata. Retrieved from: https://online.zakon.kz/Document/? doc_id=1000904.html [in Russian].

2 Bolshakova, A.M., Osipova, V.N., Romanovskaya, E.Yu. \& Yaroslavskaya, L.A. (2000). Otsenka riska vliianiia zahriazneniia atmosfernoho vozdukha benzolom na zdorove cheloveka [Risk assessment of the effect of atmospheric air pollution with benzene on public health]. Hihiena $i$ sanitaria - Hygiene and sanitation, 6, 24-28 [in Russian].

3 Agaev, F.B., Kuliev, A.S., Akbarov, A.G., \& Hasanov, M.Sh. (1992). Nekotorye metodicheskie aspekty ispolzovaniia pokazatelei zabolevaemosti i smertnosti naseleniia pri sozdanii hihienicheskoho monitorinha [Some methodological aspects of using morbidity and mortality indicators in creating hygienic monitoring]. Hihiena i sanitaria - Hygiene and sanitation, 12, 70-72 [in Russian].

4 News report (2014). 7 millionov smertei ezhehodno sviazany s zahriazneniem vozdukha [7 million deaths annually due to air pollution]. www.who.int/ru Retrieved from https://www.who.int/ru/news-room/detail/25-03-2014-7-million-premature-deathsannually-linked-to-air-pollution.html [in Russian].

5 Carington, D. (2019). Smertnost ot zahriazneniia vozdukha prevysila otsenki v dva raza [Environment Air pollution deaths are double previous estimates]. www.theguardian.com Retrieved from: https://www.theguardian.com/environment/2019/mar/12/airpollution-deaths-are-double-previous-estimates-finds-research.html [in Russian].

6 Gardiner, H. (2014). Beijing's Air Would Be Called Good In Delhi. The New York Times International — magazine, weekly (2 feburary), 9-17.

7 Opalovski, A.A. (1990). Planeta Zemlia hlazami khimika [Planet Earth through the eyes of a chemist]. Moscow: Nauka [in Russian].

8 RSE «Kazhydromet». (2016). Sostoianie zahriazneniia atmosfernoho vozdukha v horode Astane [The state of air pollution in the city of Astana]. Newsletter on the state of the environment, 212-213 [in Russian].

9 RSE «Kazhydromet». (2017). Sostoianie zahriazneniia atmosfernoho vozdukha v horode Astane [The state of air pollution in the city of Astana]. Newsletter on the state of the environment, 138-139 [in Russian].

10 RSE «Kazhydromet». (2018). Sostoianie zahriazneniia atmosfernoho vozdukha v horode Astane [The state of air pollution in the city of Astana]. Newsletter on the state of the environment, 189-190 [in Russian].

11 RSE «Kazhydromet». (2019). Sostoianie zahriazneniia atmosfernoho vozdukha v horode Astane [The state of air pollution in the city of Astana]. Newsletter on the state of the environment for the first half of, $95-97$ [in Russian].

12 RSE «Kazhydromet». (2016). Sostoianie zahriazneniia atmosfernoho vozdukha v Karahandinskoi oblasti (horod Karahanda) [The state of air pollution in Karaganda region (Karaganda city)]. Newsletter on the state of the environment, 310-311 [in Russian].

13 RSE «Kazhydromet». (2017). Sostoianie zahriazneniia atmosfernoho vozdukha v Karahandinskoi oblasti (horod Karahanda) [The state of air pollution in Karaganda region (Karaganda city)]. Newsletter on the state of the environment, 239-241 [in Russian].

14 RSE «Kazhydromet». (2018). Sostoianie zahriazneniia atmosfernoho vozdukha v Karahandinskoi oblasti (horod Karahanda) [The state of air pollution in Karaganda region (Karaganda city)]. Newsletter on the state of the environment, $291-295$ [in Russian].

15 RSE «Kazhydromet». (2019). Sostoianie zahriazneniia atmosfernoho vozdukha v Karahandinskoi oblasti (horod Karahanda) [The state of air pollution in Karaganda region (Karaganda city)]. Newsletter on the state of the environment for the first half of, 211213 [in Russian].

16 RSE «Kazhydromet». (2016). Sostoianie zahriazneniia atmosfernoho vozdukha v Karahandinskoi oblasti (horod Balkhash) [The state of air pollution in Karaganda region (Balkhash city)]. Newsletter on the state of the environment, 313 [in Russian]. 
17 RSE «Kazhydromet». (2017). Sostoianie zahriazneniia atmosfernoho vozdukha v Karahandinskoi oblasti (horod Balkhash) [The state of air pollution in Karaganda region (Balkhash city)]. Newsletter on the state of the environment, 243 [in Russian].

18 RSE «Kazhydromet». (2018). Sostoianie zahriazneniia atmosfernoho vozdukha v Karahandinskoi oblasti (horod Balkhash) [The state of air pollution in Karaganda region (Balkhash city)]. Newsletter on the state of the environment, 295 [in Russian].

19 RSE «Kazhydromet». (2019). Sostoianie zahriazneniia atmosfernoho vozdukha v Karahandinskoi oblasti (horod Balkhash) [The state of air pollution in Karaganda region (Balkhash city]. Newsletter on the state of the environment, 215 [in Russian].

20 RSE «Kazhydromet». (2016). Sostoianie zahriazneniia atmosfernoho vozdukha v Karahandinskoi oblasti (horod Zhezkazhan) [The state of air pollution in Karaganda region (Zhezkazgan city)]. Newsletter on the state of the environment, 314 [in Russian].

21 RSE «Kazhydromet». (2017). Sostoianie zahriazneniia atmosfernoho vozdukha v Karahandinskoi oblasti (horod Zhezkazhan) [The state of air pollution in Karaganda region (Zhezkazgan city)]. Newsletter on the state of the environment, 245 [in Russian].

22 RSE «Kazhydromet». (2018). Sostoianie zahriazneniia atmosfernoho vozdukha v Karahandinskoi oblasti (horod Zhezkazhan) [The state of air pollution in Karaganda region (Zhezkazgan city)]. Newsletter on the state of the environment, 297 [in Russian].

23 RSE «Kazhydromet». (2019). Sostoianie zahriazneniia atmosfernoho vozdukha v Karahandinskoi oblasti (horod Zhezkazhan) [The state of air pollution in Karaganda region (Zhezkazgan city)]. Newsletter on the state of the environment, 218 [in Russian].

24 RSE «Kazhydromet». (2016). Sostoianie zahriazneniia atmosfernoho vozdukha v Karahandinskoi oblasti (horod Temirtau) [The state of air pollution in Karaganda region (Temirtau city)]. Newsletter on the state of the environment, 317 [in Russian].

25 RSE «Kazhydromet». (2017). Sostoianie zahriazneniia atmosfernoho vozdukha v Karahandinskoi oblasti (horod Temirtau) [The state of air pollution in Karaganda region (Temitrtau city)]. Newsletter on the state of the environment, 247 [in Russian].

26 RSE «Kazhydromet». (2018). Sostoianie zahriazneniia atmosfernoho vozdukha v Karahandinskoi oblasti (horod Temirtau) [The state of air pollution in Karaganda region (Temitrtau city)]. Newsletter on the state of the environment, 300 [in Russian].

27 RSE «Kazhydromet». (2017). Sostoianie zahriazneniia atmosfernoho vozdukha v Karahandinskoi oblasti (horod Temirtau) [The state of air pollution in Karaganda region (Temitrtau city)]. Newsletter on the state of the environment, 220 [in Russian]. 